\title{
SUPERVISI KEPALA SEKOLAH UNTUK MENINGKATKAN PEMBELAJARAN GURU DI SEKOLAH
}

Tommy hendrick

tommyhendrick@gmsil.com

\begin{abstract}
ABSTRAK
Tujuan dari penelitian ini adalah untuk memperoleh informasi tentang pelaksanaan supervise akedemik yamg dilakukan oleh kepala sekolah dalam rangka mengembangkan dan membina kinerja guru. Data ini dikumpulkan dengan melalui observasi,wawancara dan dokumentasi,subjeknya adalah kepala sekolah dan guru. Penelitian ini menggunakan metode kualitatif, hasil penelitian ini menunjukan bahwa pelaksanaan supervise akademik dilakukan pada tiga langkah yaitu perencanaan, implementasi dan evaluasi.
\end{abstract}

Kata kunci: Pengawasan Akademik, Kepala Sekolah, Kinerja Guru

\section{LATAR BELAKANG}

Pendidikan sangat penting bagi kehidupan karena dengan pendidikan dapat mencerdaskan kehidupan bangsa. Hal ini sesuai dengan fungsi dan tujuan pendidikan nasional yang terdapat dalam UU No. 20 Tahun 2003 tentang system pendidikan nasional yaitu pendidikan nasional berfungsi mengembangkan kemampuan dan membentuk watak dalam serta peradaban dalam rangka mencerdaskan kehidupan bangsa,serta bertujuan untuk berkembangnya potensi peserta didik supaya menjadi manusia yang beriman dan bertaqwa kepada tuhan Yang Maha Esa, berakhlak mulia, berilmu, kreatif,mandiri.

Dalam dunia pendidikan guru sangat berperan penting dalam mencerdaskan anak didik dan bertanggungjawab atas segala sikap, tingkah laku dan perbuatan dalam membina peserta didik agar menjadi manusia yang bersusila, cakap, dan berguna bagi nusa dan bangsa. . Guru adalah pendidik profesional dengan tugas utama mendidik, mengajar, membimbing, mengarahkan, melatih, menilai, dan mengevaluasi peserta didik pada pendidikan anak usia dini jalur pendidikan formal, pendidikan dasar, dan pendidikan menengah (Peraturan menpan No. 16 tahun 2009). Karena guru mempunyai peranan yang sangat penting dalam dunia pendidikan, maka guru harus memiliki kinerja yang sangat baik.

Untuk dapat menilai serta membantu kinerja guru agar semua kegiatan dapat berjalan secara efektif dan efesien sesuai dengan apa yang telah direncanakan dan diperlukan pengawasan atau supervisi oleh kepala sekolah.

Tujuan supervisi adalah membantu guru mengembangkan kemampuannya mencapai tujuan pembelajaran yang harus dicapai peserta didik. 


\section{PEMBAHASAN}

Kepla sekolah dapat diartokan sebagai pemimpin dalam suatu organisasi, Menurut Kristiawan dkk (2017) kepala sekolah merupakan motor pengggerak, penentu arah kebijakan sekolah yang akan menentukan bagaimana tujuan-tujuan sekolah dan pendidikan pada umumnya direalisasikan. Kepala sekolah harus memiliki 3 kompetensi supervisi akademik, yaitu1) merencanakan program supervisi akademik dalam rangka peningkatan profesionalisme guru; 2) melaksanakan supervisi akademik terhadap guru dengan menggunakan pendekatan dan teknik supervisi yang tepat; dan 3) menindaklanjuti hasil supervisi akademik terhadap guru dalam rangka peningkatan profesionalisme guru (Permendiknas Nomor 13 Tahun 2007). Kegiatan supervisi pendidikan merupakan kegiatan yang wajib dilaksanakan yang bertujuan memperbaiki pembelajaran guna meningkatkan hasil pembelajaran. Menurut Arikunto (2004) supervisi memiliki fungsi meningkatkan mutu pendidikan yang tertuju pada aspek akademik yang terjadi di kelas ketika guru sedang melaksanakan pembelajaran, memicu perubahan terkait dengan pendidikan yang tertuju pada unsur- unsur yang berpengaruh terhadap peningkatan kualitas pembelajaran dan sebagai kegiatan dalam hal memimpin dan membimbing yaitu tertuju pada pelaksanaan supervisi diarahkan kepada guru dan tenaga tata usaha.

Penilaian kinerja seorang guru merupakan bagian penting dari seluruh proses kinerja guru yang bersangkutan. Menurut Martinis Yamin dan Maisah (2010: 117-125) beberapa sumber penilaian tenaga kependidikan adalah: (1) penilaian atas diri sendiri; (2) penilaian oleh siswa; (3) penilaian oleh rekan sejawat; dan (4) penilaian oleh atasan langsung.

Di dalam (sabandi, 2013) terdapat 3 pendekatan dalam supervisi yang dapat djadikan oleh supervisor sebagai langkah untuk melakukan pengembangan terhadap guru, yaitu pendekatan supervisi klinis, pengembangan dan diferensial. Supervisor dapat memilih sendiir pendekatan mana yang dirasanya dapat memberikan bantuan dan binaan kepada guru.Berbagai pendekatan tersebut dapat dihubungkan langsung dengan dimensi perhatian guru, tanggung jawab guru, kepribadian guru, kompleksitas kognitif guru sehinggan dari pendekatan tersebut dapat memberikan berbagai alternatif dalam pelaksaan supervisi.

Hal ini tidak lepas dengan peran kepala sekolah atau lembaga pendidikan dalam menyeleksi guru yang akan mengajar selain itu, supervisor dituntun agar dapat membuat guru menyesuaikan diri dengan lingkungannya. Supervisor harus dapat membuat guru mengenal strategi pembelajaran yang baik untuk digunakan dalam belajar, agar murid dapat memperhatikan dengan baik dan tidak merasa bosan. Selain itu, hal apa saja yang dapat dilakukan oleh seorang guru untuk meningkatkan kemmpuannya dalam mengajar. 
Dengan megetahui strategi yang tepat, hal yang patut dilakukan oleh guru secara tidak langsung akan menghasilkan kualitas pembeljaran yang bagus dan meningkatkan kualitas kemampuan guru dalam mengajar.

\section{KESIMPULAN}

Kepala sekolah harus dapat mengarahkan dan memimbing guru dalam melakukan pembelajaran karena kepala sekolahlah yang berperan penting dalam suatu lembaga pendidikan atau sekolah agar siswa berprestasi kedepannya, Karena apabila proses pembelajaran tidak berjalan dengan baik, tentu menandakan kegagalan seorang guru dalam mengajar yang artinya ada hal yang perlu dibenahi oleh guru tersebut agar kedepannya proses pembelajaran dapat berjaalan dengan baik.

Untuk meningkatkan kemampuan guru kepala sekolah harus memiliki 3 kompetensi supervisi akademik, yaitu1) merencanakan program supervisi akademik dalam rangka peningkatan profesionalisme guru; 2) melaksanakan supervisi akademik terhadap guru dengan menggunakan pendekatan dan teknik supervisi yang tepat; dan 3) menindaklanjuti hasil supervisi akademik terhadap guru dalam rangka peningkatan profesionalisme guru.

\section{REFERENSI}

Sabandi, ahmad. (2013). Supervisi Pendidikan Untuk Pengembangan Profesionalitas Guru berke lanjutan. Pedagogi,Jurnal Ilmu Pendidikan, XIII(2), 1-9. Retrieved from http://ejournal.unp.ac.id/index.php/pedagogi/article/view/4275/3345

Leniwati, yasir Arafat.(2017) Implementsi Supervisi Akedemik Kepala Sekolah Untuk Meningkatkan Kinerja Guru. Jurnal Manajemen, Kepemimpinan, dan Supervisi Pendidikan (2) http://jurnal.univpgri-palembang.ac.id/index.php/JMKSP/ article/view/1158

Purwanto, M. Ngalim. (2002). Administrasi dan Supervisi Pendidikan. Bandung Remaja Rosda karya 